\title{
A CITY THAT RESISTED MITHRIDATES
}

\begin{abstract}
This paper examines the question of a city that offered successful resistance to the Pontic troops during the early stages of the First Mithridatic War. The main narrative source, Appian's Mithridatica, informs us that a Magnesia surrendered to the king, but that another city of the same name offered noteworthy resistance. However, Appian does not clearly differentiate whether the defiant city was the Lydian Magnesia (on Mt. Sipylus) or the Carian one (on the river Maeander). Other classical writers offer additional but often contradictory information. The same confusion exists in much of the modern literature on the Mithridatic wars. A satisfactory solution can be reached, however, by a careful reexamination of the existing sources and their reliability, and by employing a recent numismatic find.
\end{abstract}

Early in 88 BC, king Mithridates VI had western Asia Minor under his feet. After inflicting crushing defeats on the forces of the Bythinian king Nicomedes IV and on the Asian levies raised by Roman officials, the Pontic ruler advanced to the Aegean seaboard encountering very little resistance. ${ }^{1}$ Most of the cities in the western part of the Anatolian peninsula opened their gates to him and greeted advancing troops with cheers. Even the impregnable fortress of Pergamum, the capital of the former Attalid kingdom and now the seat of the Roman governor of Asia, submitted without opposition. Ephesus, the major urban and commercial center of the region, did the same. ${ }^{2}$ The citizens would later claim that they abandoned Romans only temporarily, out of fear

1 General overview and analysis of the First Mithridatic war: Th. Reinach, Mithradates Eupator König von Pontos, Leipzig, 1895, pp. 115-205; D. Magie, Roman Rule in Asia Minor to the End of the Third Century After Christ I, Priceton, 1950, pp. 208-231; H. A. Ormerod, Pontus and Its Neighbours: The First Mithridatic War, CAH IX, Cambridge, 1951, pp. 238-260; A. N. Sherwin-White, Roman Foreign Policy in the East 168 B.C. to A.D. 1, London 1984, pp. 121-148; B. McGing, The Foreign Policy of Mithridates VI Eupator, King of Pontus, Leiden, 1986, pp. 89-131; J. G. F, Hind, Mithridates, CAH IX ${ }^{2}$, Cambridge, 1992, pp. 143-164; L. Ballesteros Pastor, Mitrídates Eupátor, rey del Ponto, Granada 1996, pp. 81-189; R. M. KalletMarx, Hegemony to Empire: The Development of the Roman Imperium in the East from 148 to 62 BC, Berkley - Los Angeles - Oxford, 1996, pp. 250-264.

${ }^{2}$ App. Mith. 3. 17-21. 
and necessity. ${ }^{3}$ However, there were some cities still loyal to their alliance with Rome, or simply not as convinced by the early Pontic victories. They refused to yield and offered what resistance they could to the king's advance. Laodicea on the Lycus was first to do so, but it surrendered after a short siege. Further in the south, cities such as Stratonicea and Tabae in Caria, and Telmessus in Lycia opposed the Pontic king's progress, with different results. Later, while his forces were advancing across the Aegean, the king himself besieged Rhodes and Patara, but failed to take either. ${ }^{4}$

Among these courageous communities, ancient authors mention one called Magnesia. It not only refused to submit but also offered a very persistent and well-organized resistance. Even Archelaus, the best of the king's generals, lost an engagement with the Magnesians and was himself wounded. However, Appian, our main source on the Mithridatic wars, presents these events in such a way that it causes significant confusion for the reader, the confusion that is reflected in the works of modern scholars. "After appointing satraps over the various nations he [Mithridates] proceeded to Magnesia, Ephesus, and Mytilene, all of which received him gladly... Against those Magnesians, Paphlagonians, and Lycians who still opposed him he directed his generals to make

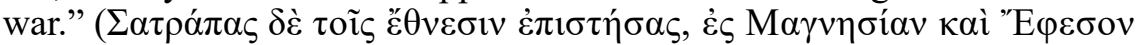

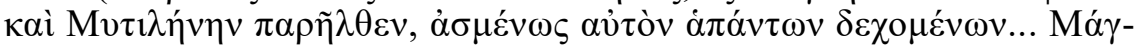

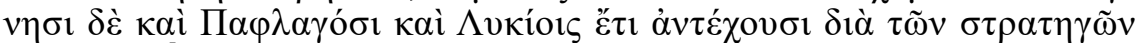
$\dot{\varepsilon} \pi \mathrm{\nu} \lambda \varepsilon \dot{\varepsilon} \mu \varepsilon \mathrm{l}) .{ }^{5}$ One Magnesia opened its gates to the king, while another city of the same name chose to fight. Is the defiant city the northern one in Lydia, by the mountain Sipylus, or the southern in Caria (Ionia), on the river Maeander?

That a city named Magnesia fought against Mithridates is confirmed by Livy ${ }^{6}$ and Plutarch ${ }^{7}$ but without further details. Other sources supplement this but with inconsistent information. Describing the beginning of the Roman siege of Athens in $86 \mathrm{BC}$, Pausanias states that "In the engagement that ensued the Romans won a decisive victory; Aristion and the Athenians they drove in flight into the city, Archelaus and the barbarians into the Peiraeus. This Archelaus was another general of Mithridates, whom earlier than this the Magnetes, who inhabit Sipylus, wounded when he raided their territory, killing most of

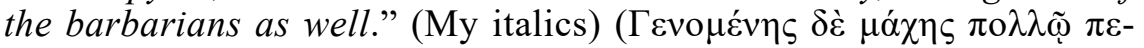

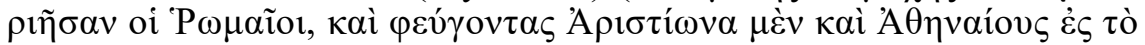

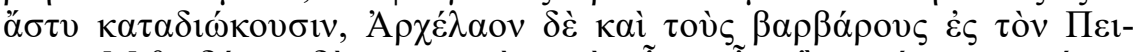

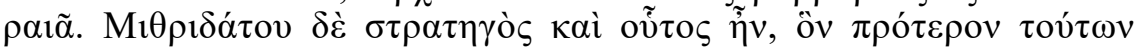

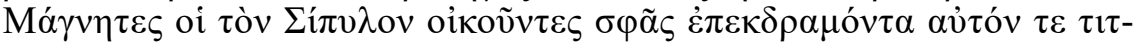

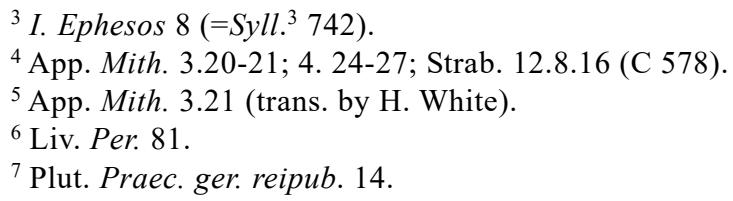




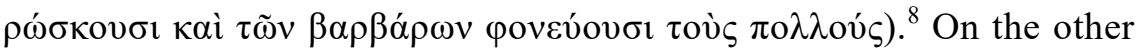
hand, Tacitus wrote that Magnesia on the Meander was rewarded by Sulla for its conduct during The First Mithridatic war: "The Magnesians, who followed, rested their case on the rulings of Lucius Scipio and Lucius Sulla, who, after their defeats of Antiochus and Mithridates respectively, had honored the loyalty and courage of Magnesia by making the shrine of Leucophryene Diana an inviolable refuge." (Proximi hos Magnetes L. Scipionis et L. Sullae constitutis nitebantur, quorum ille Antiocho, hic Mithridate pulsis fidem atque virtutem Magnetum decoravere, uti Dianae Leucophryenae perfugium inviolabile foret). ${ }^{9}$ It stands to reason that citizens who betrayed the Romans in war would receive no rewards, least of all rewards for their good faith ( $\mathrm{fi}$ des) and courage (virtus). This was sometimes taken to be in contradiction with a statement of Strabo, that Romans made Magnesia ad Si-

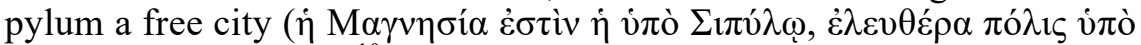
'P $\left.\omega \mu \alpha i \omega \nu \kappa \varepsilon \kappa \rho \uparrow \varepsilon^{\prime} \nu \eta\right),{ }^{10}$ although Strabo does not specify the circumstances of this grant.

For the most part, historians simply choose to believe either Tacitus or Pausanias. Late in the $19^{\text {th }}$ century, in his imposing monograph on Mithridates VI, Théodore Reinach decided for the Magnesia ad Sipylum. ${ }^{11}$ His opinion greatly influenced later scholars. Those who sided with Reinach include M. I. Rostovtzeff, ${ }^{12}$ H. Ormerod ${ }^{13}$ and D. Magie. ${ }^{14}$ Others, including L. Bürchner ${ }^{15}$ and O. Kern ${ }^{16}$ opted for the southern city. In 1986, in his outstanding work on the foreign policy of Mithridates VI, Brian McGing made a strong claim that the city in question was actually Magnesia on the Maeander: "Some of the staunchest opposition we hear about was that offered by Magnesia on Maeander, which fought off the Pontic assault with great courage." 17 In a footnote he added: "Not Magnesia near Sipylus, although there is confusion in the sources, and in modern literature..." 18 The reason why McGing preferred the testimony of Tacitus over that of Livy and Pausanias was the assumption that the Roman historian utilized the acta Senatus: "As Tacitus was surely using the acta Senatus in Ann. $3.60 \mathrm{ff}$

${ }^{8}$ Paus. 1.20 .5 (trans. by W. H. S. Jones).

${ }^{9}$ Tac. Ann. 3.62 (trans. by J. Jackson).

${ }^{10}$ Strab. 13.3 .5 (621). p. 122.

${ }^{11}$ Th. Reinach, Mithradates Eupator, König von Pontos, Leipzig, 1895, p. 120, n. 5;

${ }^{12}$ M. Rostovtzeff, The Social and Economic History of the Hellenistic World II, Oxford, 1941, pp. 937-938.

${ }^{13}$ H. A. Ormerod, op. cit., p. 241.

${ }^{14}$ D. Magie, op. cit. I, p. 215; II, pp. 1102-1103, n. 32.

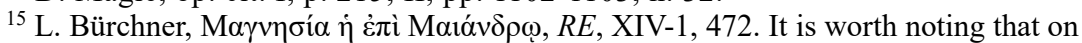
the very next page, in a reference dedicated to Magnesia ad Sipylum, W. Ruge claims that it was this city that remained loyal to Romans during the war (RE, XIV-1, 473).

${ }^{16}$ O. Kern, Die Inschriften von Magnesia am Maeander, Berlin, 1900, p. XVI.

${ }^{17}$ B. McGing, op. cit., 1986, p. 111.

${ }^{18}$ Ibid., p. 111, n. 110. 
(see R. Syme, Tacitus vol. 1 [1958] 285), it looks as if his statement on the matter should definitely be right against what is more of a passing reference by Pausanias." " 19 an official document of the Roman Senate any confusion regarding the name or identity of the mentioned city would be excluded. Thus, the argument goes, Magnesia must be the one on the Maeander. Several scholars accepted McGing's judgment on the issue, ${ }^{20}$ but many others did not, in spite of the great general impact of his book. ${ }^{21}$

However, the opinion that "Tacitus was surely using the acta Senatus in Ann. 3.60ff" was not widely held even at the time when McGing wrote his book. Some scholars speculated on Tacitus' reliance on documentary evidence, ${ }^{22}$ but conclusive evidence is lacking. "We know that ancient historians normally did research only in connection with contemporary events which they were the first to describe... Tacitus, no doubt, read with care the acta senatus... for the period of Domitian, in which he broke new ground. But we cannot assume without very good reasons that he did the same thing systematically for the period from Tiberius to Titus, for which he could use literary sources." 23 If there was no need to use Senate proceedings for the reign of Tiberius in general, it was even less necessary to do so to check the marginal claim connected to an event of the early $1^{\text {st }}$ century BC. In fact, there is indication that Tacitus did not rely very often on documentary evidence. True, there is a place in the Annales where he explicitly mentions the usage of "the registers of the Senate" (commentarii

\section{Ibid.}

${ }^{20}$ Cf. for example, J. G. F. Hind, Mithridates, CAH IX ${ }^{2}$, Cambridge, 1992, p. 147: "At Magnesia (probably the Carian one on the Maeander) resistance was offered, and Archelaus was wounded."; A. Keaveney, Sulla: The Last Republican, London, New York, 20053 , p. 191; A. Mayor, The Poison King: The Life and Legend of Mithradates, Rome's Deadliest Enemy, Princeton, Oxford, 2010, p. 157.

${ }^{21}$ Among others L. Ballesteros-Pastor, Mitrídates Eupátor, rey del Ponto, 1996, p. 101, n. 67; A. Mastrocinque, Appiano. Le Guerre Mitridatiche, Milan 1999, p. 189, n. 15; M. Arslan, Mithradates VI Eupator, Roma'nin Büyük Düssmani, Ocak, 2007, p. 151, 156.

${ }^{22}$ Above all R. Syme, Tacitus I, Oxford, 1958, 285, who showed firm conviction in this matter (reinforced in id., Tacitus: Some Sources of his Information, The Journal of Roman Studies, 72 (1982), p. 73). Also E. Cizek, L'Epoque de Néron et ses controverses idéologiques, Leiden, 1972, p. 18 ("Nous ne pensons pas que Tacite ait méconnu les sources non-littéraires, telles que les archives de l'Etat, acta senatus et les documents, nous croyons qu'il les avait lus, même s'il les a fort rarement mentionnés, ce qui arrivait souvent aux auteurs antiques."), and R. J. A. Talbert, The Senate of Imperial Rome, Princeton, 1984, pp. 324-326. But even Richard Talbert, who argued strongly in favor of Tacitus using the acta Senatus, was obliged to admit that "we still lack proof of this extensive use" (id., Tacitus and the "Senatus Consultum de Cn. Pisone Patre", The American Journal of Philology, 120-1, 1999, p. 89).

${ }^{23}$ A. Momigliano, The Classical Foundations of Modern Historiography, Berkeley, Los Angeles, London, 1990, p. 100. 
Senatus), but this is a solitary example. ${ }^{24}$ More often, he refers to other writers as his sources of information, sometimes even for the Senate's proceedings. ${ }^{25}$ These references are difficult to explain if he really did use the acta Senatus in any systematic fashion. It seems safe to assume that Tacitus used the acta occasionally, but that other writers were his primary source of information. ${ }^{26}$ The best course is to go with the careful judgement of Momigliano: "What we can say is that our present evidence offers nothing to support the anachronistic image of Tacitus passing his mornings in the archives of the Roman Senate."27 Furthermore, Tacitus was far from an infallible writer the older generations of scholars made him to be: he did make a number of factual errors and sometimes would freely reshape his source material. ${ }^{28}$ The passage in his Annales mentioning Magnesia on the Meander was based on information found in some earlier Roman writer with whom the mistake probably originated.

That leaves us with the statement of Pausanias. Is there a reason to assume that he made an error in the first place, even if his remark was "casual"? True enough, he is also known to make mistakes regarding

${ }^{24}$ Tac. Ann. 15.74: Reperio in commentariis Senatus Cerialem Anicium consulem designatum pro sententia dixisse ut templum divo Neroni quam maturrime publica pecunia poneretur.

${ }^{25}$ In Ann. 1.81, discussing the consular elections of 15 AD, Tacitus admits his confusion by the event, because historians and imperial speeches he read give conflicting information: De comitiis consularibus, quae tum primum illo principe ac deinceps fuere, vix quicquam firmare ausim: adeo diversa non modo apud auctores, sed in ipsius orationibus reperiuntur. Modo subtractis candidatorum nominibus originem cuiusque et vitam et stipendia descripsit ut qui forent intellegeretur; aliquando ea quoque significatione subtracta candidatos hortatus ne ambitu comitia turbarent, suam ad id curam pollicitus est. Likewise, in Ann. 2.88 it is explicitly stated that the information regarding an official letter, read in Senate, was obtained through several earlier writers: Reperio apud scriptores senatoresque eorundem temporum Adgandestrii principis Chattorum lectas in senatu litteras, quibus mortem Arminii promittebat si patrandae neci venenum mitteretur, responsumque esse non fraude neque occultis, sed palam et armatum populum Romanum hostis suos ulcisci. In both cases, the usage of narrative sources would be redundant (and confusion avoided), if he actually used the acta Senatus.

${ }^{26}$ See F. R. D. Goodyear, History and Biography, in: E. J. Kenney, W. A. Clausen (eds.), The Cambridge History of Classical Literature II: Latin Literature, Cambridge, 1982, p. 648: "Tacitus drew his material from general and special histories (cf. Ann. 1.69.2), memoirs (cf. Ann. 4.53.2), personal enquiry (cf. Plin. Epist. 6.16.1), and the official report of senatorial proceedings, acta Senatus. It is debatable whether he made the fullest use of these diverse sources. Perhaps he might have used the acta as some partial control upon the historians, but in fact he seems to use them only intermittently, for variety or to preserve a semblance of traditional subject matter: thus minor senatorial business tends to appear at the end of each year's record. We cannot well judge how conscientiously Tacitus handled primary evidence, since he mainly depends on secondary sources." Cf. G. B. Townend, Traces in Dio Cassius of Cluvius, Aufidius and Pliny, Hermes 89-2, 1961, pp. 238-239.

${ }^{27}$ A. Momigliano, op. cit., p. 112.

${ }^{28}$ Cf. K. Wellesly, Can You Trust Tacitus, Greece \& Rome, 1-1, 1954, pp. 13-33. 
historical matters, especially when more distant past is involved. However, recent scholarship tends to judge his reliability more favorably, and the mention of Magnesia is something of a special case. Indeed, it could well have been an episode of personal importance for him. Pausanias was a native of Roman Lydia, in fact almost certainly a native of Magnesia ad Sipylum. ${ }^{29}$ A success against the forces of Mithridates, achieved at a critical moment when the majority of the communities in the Western Anatolia preferred to submit, certainly belonged to the outstanding events of city's history. It is something that would be preserved and cherished in public memory. There was certainly a spark of local pride in author's decision to mention a Pontic attack on his hometown in what was otherwise an unrelated context: the Romans may have defeated a famous general of Mithridates, but this was only a repetition of an earlier victory of the Magnesians. Of course, size and significance of such event would be exaggerated and probably embellished with imaginative details (was Archelaus actually personally involved in the combat, or is his wounding a later addition?). Nevertheless, of all the possible explanations, the one where an otherwise wellinformed native of Magnesia ad Sipylum confuses a crucial event in the history of his hometown with an incident that took place in another city (because the names of two communities were similar!) seems the least likely.

Another point of interest for the present discussion is the king's itinerary during the conquest of Asia in $88 \mathrm{BC}$. Mithridates was not present during the attack on Magnesia, nor was the attack carried out by the main army. The citizens fought off a smaller force, led by one of the king's generals. The information found in various sources on the cities surrendering (or resisting) the king himself allows a reliable reconstruction of the king's route in the year $88 \mathrm{BC}$. This was already done by Reinach, Magie, McGing and others. ${ }^{30}$ According to Appian, the king entered Phrygia from the north (via the upper Sangarius valley), then "he overran the rest of Phrygia, together with Mysia

${ }^{29}$ Ch. Habicht, Pausanias und seine „Beschreibung Grichenlands“, München, 1985, pp. 25-28; K. W. Arafat, Pausanias' Greece: Ancient Artists and Roman Rulers, Cambridge, 1996, p. 8; A. Lesky, Geschichte der griechischen Literatur, München $1999,{ }^{3}$ p. 955; E. Bowie, Inspiration and Aspiration: Date, Gender and Readership, in: S. E. Alocock, J. F. Cherry, J. Elsner (eds.), Pausanias: Travel and Memory in the Roman Greece, Oxford, 2001, p. 24; M. Pretzler, Pausanias: Travel Writing in Ancient Greece, Bristol, 2007, p. 21. In Paus. 5.13.7, in a rare self-revealing moment, author ac-

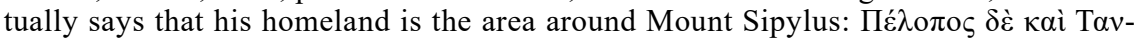

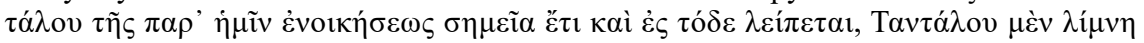

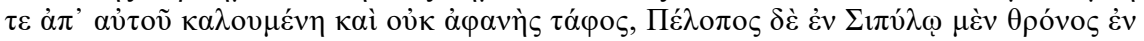

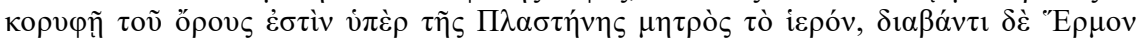

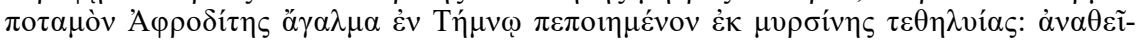

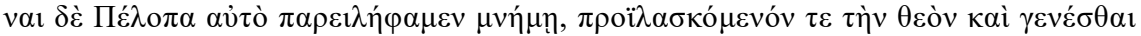

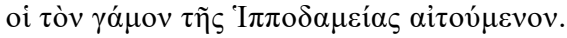

30 Th. Reinach, op. cit., 119-123; D. Magie, op. cit., pp. 212-215; B. McGing, op. cit., pp. 109-111. 
and those parts of Asia which had been lately acquired by the Romans. Then he sent his officers to the adjoining provinces and subjugated

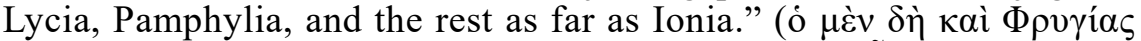

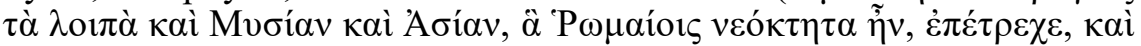

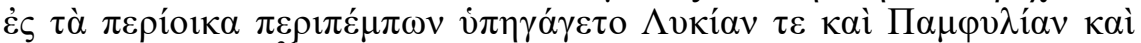

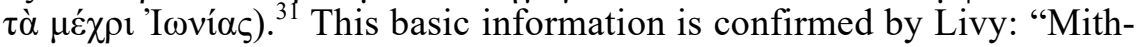
ridates, king of Pontus, seized Bithynia and Cappadocia, after having driven the Roman general, Aquilius, out of them; and at the head of a great army entered Phrygia, a province belonging to the Roman people." (Mithridates, Ponti rex, Bithynia et Cappadocia occupatis et pulso Aquilio legato Phrygiam, provinciam populi Romani, cum ingenti exercitu intravit.). ${ }^{32}$

Mithridates conquered central Phrygia and (eastern) parts of Mysia, after which he moved south, until reaching Apamea in Phrygia. From there he proceeded westward to Laodicea on the Lycus, ${ }^{33}$ where we find one of the Roman commanders, Quintus Oppius, with some mercenary troops. After taking the city, the king sent some detachments to subjugate southern regions of the peninsula (Caria, Lycia, Pamphylia), while he himself, with the bulk of his army, continued the westward march through the valley of the Maeander River, until he reached Ephesus and the Aegean coast. Magnesia on the Maeander stood right on his path. If any resistance was offered, it would have been against the king himself and his main army, with little prospect of success. Actually, Appian says that there was no resistance. Continuing form the king's capture of Laodicea, he states: "After appointing satraps over the various nations he proceeded to Magnesia, Ephesus, and Mytilene, all of which received him gladly. The Ephesians overthrew the Roman statues that had been erected in their cities - for which they paid the penalty not long afterward. On his return from Ionia Mithridates took the city of Stratonicea, imposed a pecuniary fine

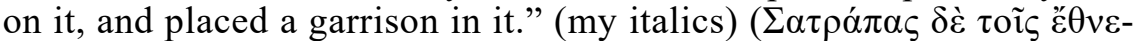

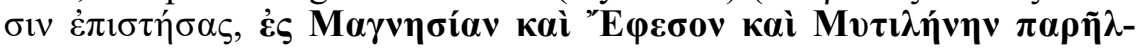

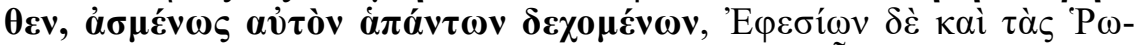

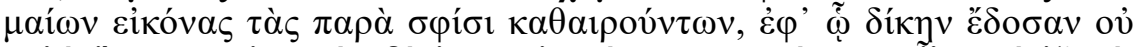

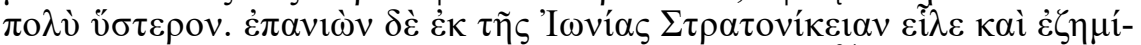

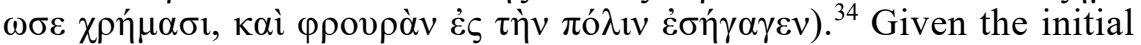
position of his army (around Laodicea, in the upper valley of the Maeander River), the city in question can only be Magnesia on the Maeander. ${ }^{35}$ Cicero testifies that Tralles, situated in the Maeander valley

\footnotetext{
${ }^{31}$ App. Mith. 3.20 (trans. by H. White).

${ }^{32}$ Liv. Per. 77 (trans. by W. A. McDevitte).

${ }^{33}$ D. Magie, op. cit., p. 214.

${ }^{34}$ App. Mith. 3.21 (trans. by H. White).

${ }^{35}$ Perhaps this is the reason why Magie claimed that "two cities are clearly distinguished" in Appian Mith. 3.21 (op. cit., II, p. 1102, n. 32), a statement that McGing (op. cit., p. 111, n. 110) considered to be erroneous.
} 
halfway between Laodicea and Magnesia, surrendered to Pontic troops. ${ }^{36}$ After passing through Magnesia and Ephesus, the king captured the neighboring Stratonicea in Caria and spent some time there.

This reconstruction is the only one consistent with all of the available evidence. It also explains the successful resistance of the Lydian Magnesia. That city was outside the main Pontic advance. It never faced the king or the main Pontic force and only after Smyrna, Pergamum and Sardis were already in king's hands was it threatened. Its citizens had plenty of time to decide what to do and to prepare for the subsequent attack. ${ }^{37}$ Such freedom of action was not available to the city in the Maeander valley, laying on one of the great thoroughfares of the Anatolian peninsula.

A recent striking numismatic discovery provides the final piece of evidence. In 2003 a previously unknown coin of Magnesia on the Maeander came to light. ${ }^{38}$ Another was discovered and auctioned in $2008 .^{39}$ The coin in question is a didrachm, weighting circa $6.04 \mathrm{~g}$, issued probably between 88 and $85 \mathrm{BC}$. Bust of Artemis with earring, metal band in her hair, bow stylized in the shape of stag's head, and quiver on her back, is featured on the obverse. A grazing (drinking?) stag, standing on a narrow strip of meandering pattern with a triangular monogram between his legs, is on the reverse. The legend reads $M A \Gamma N H T \Omega N$ (reverse, above, interrupted by a star between $H$ and $T$ ), and MAIAN $\triangle P I O \Sigma A P T E M I \triangle<\Omega P O>Y$ - the name of the monetary magistrate (reverse, below, in exergue). ${ }^{40}$ The iconography of the coin is alien to the Magnesian tradition and shows strong influence of Mithridates' coinage. The bust of Artemis is different from the earlier civic Artemis-imagery, being modeled after the Pontic bronze and silver coins. The grazing stag is a complete oddity in the local coinage: it is a borrowing from the contemporary gold and silver Mithridatic issues struck at Pergamum. ${ }^{41}$ This silver issue is paralleled by several issues of bronze coins, known before but not fully understood until recently. ${ }^{42}$ If the suggested interpretation is correct, ${ }^{43}$ it could only mean that Magnesia on the Maeander joined the Pontic king willingly, and publicly

${ }^{36}$ Cic. Pro Flacc. 57.

${ }^{37}$ Plut. Praec. ger. reipub. 14 alludes to these preparations.

${ }^{38} \mathrm{Ph}$. Kinns, A New Didrachm of Magnesia on the Maeander, The Numismatic Chronicle, 166, 2006, pp. 41-47.

39 R. Ashton, The Use of Cistoforic Weight-Standard Outside the Pergamene Kingdom, in: P. Thonemann (ed.), Attalid Asia Minor: Money, International Relations and the State, Oxford, 2013, p. 250, n. 17.

${ }^{40}$ The same city official is mentioned in I.Magnesia 100b, 43-44 $\left(=\right.$ Syll. $^{3}$ 695b,

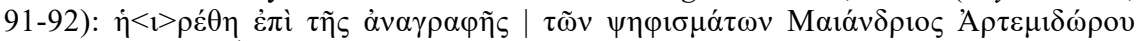
(the end of the $2^{\text {nd }}$ century BC).

${ }^{41} \mathrm{Ph}$. Kinns, op. cit., pp. 41, 46-47 (cf. pl. 13).

${ }^{42}$ Ibid., pp. 42-46.

${ }^{43}$ It is accepted as such by $\mathrm{P}$. Thonemann, The Meander Valley: A Historical Geography from Antiquity to Byzantium, Cambridge, 2011, p. 39. 
celebrated the decision. Not only does Magnesia ad Sipylum now seem to be "the more likely option" as the stronghold of resistance, ${ }^{44}$ but the latest evidence also serves to round up what was already a compelling case for the Lydian city.

\title{
BIBLIOGRAPHY
}

\author{
Ancient Authors:
}

Appian's Roman History II, trans. H. White, London - Cambridge MA, 1962.

The Geography of Strabo V, trans. H. L. Jones, London - Cambridge MA, 1969.

History of Rome by Titus Livius: The Epitomes of the Lost Books, trans. W. A. McDevitte, London, 1850.

Cicero, X: In Catilinam I-IV, Pro Murena, Pro Sulla, Pro Flacco, trans. C. Macdonald, London - Cambridge MA, 1976.

Pausanias Description of Greece I, trans. W. H. S. Jones, London - New York, 1918.

Pausanias Description of Greece II, trans. W. H. S. Jones, H. A. Ormerod, London New York, 1926.

Plutarch, Moralia X, trans. H. N. Fowler, London - Cambridge MA, 1936.

Tacitus, The Histories. The Annals II, trans. C. H. Moore, J. Jackson, London-New York, 1931.

\section{Epigraphic Corpora:}

Dittenberger, W., Sylloge Inscriptionum Graecarum II $^{3}$, Leipzig, 1917.

Kern, O., Die Inschriften von Magnesia am Maeander, Berlin, 1900.

Wankel, H., Die Inschriften von Ephesos Ia, Bonn, 1979.

\section{Literature:}

Arafat, K. W., Pausanias' Greece: Ancient Artists and Roman Rulers, Cambridge, 1996.

Ashton, R., The Use of Cistoforic Weight-Standard Outside the Pergamene Kingdom, in: P. Thonemann (ed.), Attalid Asia Minor: Money, International Relations and the State, Oxford, 2013, pp. 245-264.

Ballesteros Pastor, L., Mitrídates Eupátor, rey del Ponto, Granada 1996.

Bowie, E., Inspiration and Aspiration: Date, Gender and Readership, in: S. E. Alocock, J. F. Cherry, J. Elsner (eds.), Pausanias: Travel and Memory in the Roman Greece, Oxford, 2001, pp. 21-32.

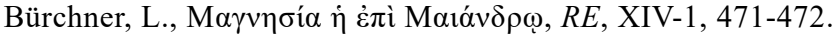

Cizek, E., L'Epoque de Néron et ses controverses idéologiques, Leiden, 1972.

Goodyear, F. R. D., History and Biography, in: E. J. Kenney, W. A. Clausen (eds.), The Cambridge History of Classical Literature II: Latin Literature, Cambridge, 1982, pp. 639-666.

Habicht, Ch., Pausanias und seine ,Beschreibung Grichenlands “, München, 1985.

Hind, J. G. F., Mithridates, CAH IX ${ }^{2}$, Cambridge, 1992, pp. 129-164.

${ }^{44}$ Ph. Kinns, op. cit., p. 47. 
Kallet-Marx, R. M., Hegemony to Empire: The Development of the Roman Imperium in the East from 148 to 62 BC, Berkley - Los Angeles - Oxford, 1996.

Keaveney, A., Sulla: The Last Republican, London, New York, $2005^{3}$.

Kinns, Ph., A New Didrachm of Magnesia on the Maeander, The Numismatic Chronicle, 166, 2006, pp. 41-47.

Lesky, A., Geschichte der griechischen Literatur, München 1999. ${ }^{3}$

Magie, D., Roman Rule in Asia Minor to the End of the Third Century After Christ III, Priceton, 1950.

Mastrocinque, A., Appiano. Le Guerre Mitridatiche, Milan 1999.

Mayor, A., The Poison King: The Life and Legend of Mithradates, Rome's Deadliest Enemy, Princeton, Oxford, 2010.

McGing, B., The Foreign Policy of Mithridates VI Eupator, King of Pontus, Leiden, 1986.

Momigliano, A., The Classical Foundations of Modern Historiography, Berkley, Los Angeles, London, 1990.

Ormerod, H. A., Pontus and Its Neighbours: The First Mithridatic War, CAH IX, Cambridge, 1951, pp. 238-260.

Pretzler, M., Pausanias: Travel Writing in Ancient Greece, Bristol, 2007.

Reinach, Th., Mithradates Eupator König von Pontos, Leipzig, 1895.

Rostovtzeff, M., The Social and Economic History of the Hellenistic World I-II, Oxford, 1941.

Sherwin-White, A. N., Roman Foreign Policy in the East 168 B.C. to A.D. 1, London 1984.

Syme, Tacitus I, R., Oxford, 1958.

Syme, R., Tacitus: Some Sources of his Information, The Journal of Roman Studies, 72, 1982, pp. 68-82.

Talbert, R. J. A., Tacitus and the "Senatus Consultum de Cn. Pisone Patre", The American Journal of Philology, 120-1, 1999, pp. 89-97.

Talbert, R. J. A., The Senate of Imperial Rome, Princeton, 1984.

Thonemann, P., The Meander Valley: A Historical Geography from Antiquity to Byzantium, Cambridge, 2011.

Townend, G. B., Traces in Dio Cassius of Cluvius, Aufidius and Pliny, Hermes 89-2, 1961, pp. 227-248.

Wellesly, K., Can You Trust Tacitus, Greece \& Rome, 1-1, 1954, pp. 13-33. 